\title{
Do nematode mucus secretions affect bacterial growth?
}

\author{
Tom Moens ${ }^{1, *}$, Giovanni Amadeu Paiva dos Santos ${ }^{1,2}$, Fabiano Thompson ${ }^{3,4}$, \\ Jean Swings ${ }^{3,4}$, Verônica Fonsêca-Genevois ${ }^{2}$, Magda Vincx ${ }^{1}$, Ilse De Mesel ${ }^{1,3}$ \\ ${ }^{1}$ Ghent University, Biology Department, Marine Biology Section, Krijgslaan 281/S8, 9000 Gent, Belgium \\ ${ }^{2}$ Federal University of Pernambuco, Centre for Biological Sciences, Zoology Department, Avenida dos Reitores 1235-Cidade \\ Universitaria, 50670-420 Recife-Pernambuco, Brazil \\ ${ }^{3}$ Ghent University, Laboratory of Microbiology, K.L. Ledeganckstraat 35, 9000 Gent, Belgium \\ ${ }^{4} \mathrm{BCCM}^{\mathrm{TM}} / \mathrm{LMG}$ Culture Collection, Laboratory of Microbiology, K.L. Ledeganckstraat 35, 9000 Gent, Belgium
}

\begin{abstract}
Many aquatic nematodes secrete mucus while moving, and prominent microbial growth on nematode mucus tracks has been observed. This has been interpreted as a mutualistic interaction in which nematodes may feed on the micro-organisms that colonise their tracks (i.e. the mucus-trap hypothesis). Because of recent evidence that nematodes can affect bacterial community composition, we tested whether bacterial communities growing on nematode mucus differ from extant communities. We characterised the bacterial epigrowth of tracks produced on agar by 2 estuarine nematode species (the facultative predator Adoncholaimus fuscus and the bacterivore Geomonhystera disjuncta) and compared it to that of artificial tracks and to the bacterial inocula. The experiment lasted $8 \mathrm{~d}$, with bacterial community analyses (using fatty acid methyl ester [FAME] analysis) after 2, 4, 6 and $8 \mathrm{~d}$. Although our experimental design promoted a low-diversity bacterial community, multidimensional scaling generally separated communities on nematode tracks from inocula, artificial track communities typically being intermediate and highly variable. In a total of 6 bacterial inocula spotted with A. fuscus, only 1 bacterial strain was recorded on nematode tracks, compared to 6 on artificial tracks and 7 in the inocula. In addition, colony morphology of this particular bacteria, Pseudoalteromonas tetraodonis, was less diverse on nematode tracks than on artificial tracks or inocula. Treatments with G. disjuncta yielded similar yet less consistent and less pronounced results. Our results suggest that nematode mucus may affect colonisation and succession patterns of bacteria. This may have important implications for food-web interactions and ecosystem functions involving both bacteria and nematodes.
\end{abstract}

KEY WORDS: Nematodes - Bacteria $\cdot$ Nematode mucus · Microbial community composition · Facilitation $\cdot$ Microbial food webs

\section{INTRODUCTION}

Decomposition and nutrient mineralisation by microbial communities in aquatic sediments often proceed faster and/or more efficiently in the presence of microbial grazers, such as flagellates, ciliates and nematodes (Johannes 1965, Findlay \& Tenore 1982). Such stimulatory effects are usually attributed to (1) grazing, which hampers immobilisation of limiting nutrients in micro- bial biomass (Ingham et al. 1985, Ferris et al. 1997), and (2) bioturbation, which enhances fluxes of oxygen and nutrients through sediments (Alkemade et al. 1992b, Aller \& Aller 1992). Nematodes are usually the predominant metazoans in estuarine and marine soft sediments (Heip et al. 1985), and have indeed been shown to affect microbial activity and/or decomposition processes (Findlay \& Tenore 1982, Alkemade et al. 1992a,b, Lillebø et al. 1999, De Mesel et al. 2003). 
Grazing and bioturbation are not, however, the only mechanisms through which grazers interfere with microbial communities. Many nematodes also secrete mucus which, e.g., has been shown to agglutinate sediment and detrital particles (Riemann \& Schrage 1978). Riemann \& Schrage (1978) also observed prominent microbial growth on the tracks of marine nematodes and argued that (1) the mucus tracks provide bacteria with optimal growth conditions, and (2) micro-organisms trapped in the mucus serve as food for the nematodes; this is commonly referred to as the mucus-trap hypothesis. Recently, the functional implications of this phenomenon have been re-interpreted against the background of an extensive historical treatment of relevant observations (Riemann \& Helmke 2002), but the general fact that nematode tracks - at least in artificial substrates - tend to become heavily colonised with micro-organisms remains.

The mucus trails of an estuarine nematode became covered with monopopulations of a unicellular microalga, suggesting that micro-organisms growing on nematode tracks may differ from extant microbial communities (Warwick 1981). De Mesel et al. (2004) demonstrated that bacterial community composition and diversity can be top-down affected by nematodes, with different nematode species varying in their effects on microbial communities. Little work has been done to further elucidate this kind of nematode-microbial interaction.

These observations raise the question as to whether nematode mucus may affect the composition and diversity of microbial communities. Therefore, we have performed a laboratory experiment to characterise the bacterial epigrowth of nematode tracks and compare it to that in the inoculum and in artificial tracks.

\section{MATERIALS AND METHODS}

We spotted microbial inocula, obtained from various microhabitats (different types of sediment, different types of macrophyte detritus) in the Paulina salt marsh and on the adjacent intertidal flat, in the centre of petri dishes (5 $\mathrm{cm}$ inner diameter) coated with an agar layer (Fig. 1). The Paulina site is located in the polyhaline reach of the Westerschelde Estuary (SW Netherlands). The agar medium $(0.7 \%$ final concentration, salinity of 25) consisted of a mixture of bacto- and nutrient agar (DIFCO) in a 3:1 ratio (w/w). We made artificial tracks by carving the agar surface from the central inoculum towards the edges with the tip of a fine, sterile Tungsten wire needle. We then introduced nematodes in the centre of the plates and allowed them to move freely. For reasons of comparability with previous work (Riemann \& Schrage 1978, Riemann \& Helmke 2002),

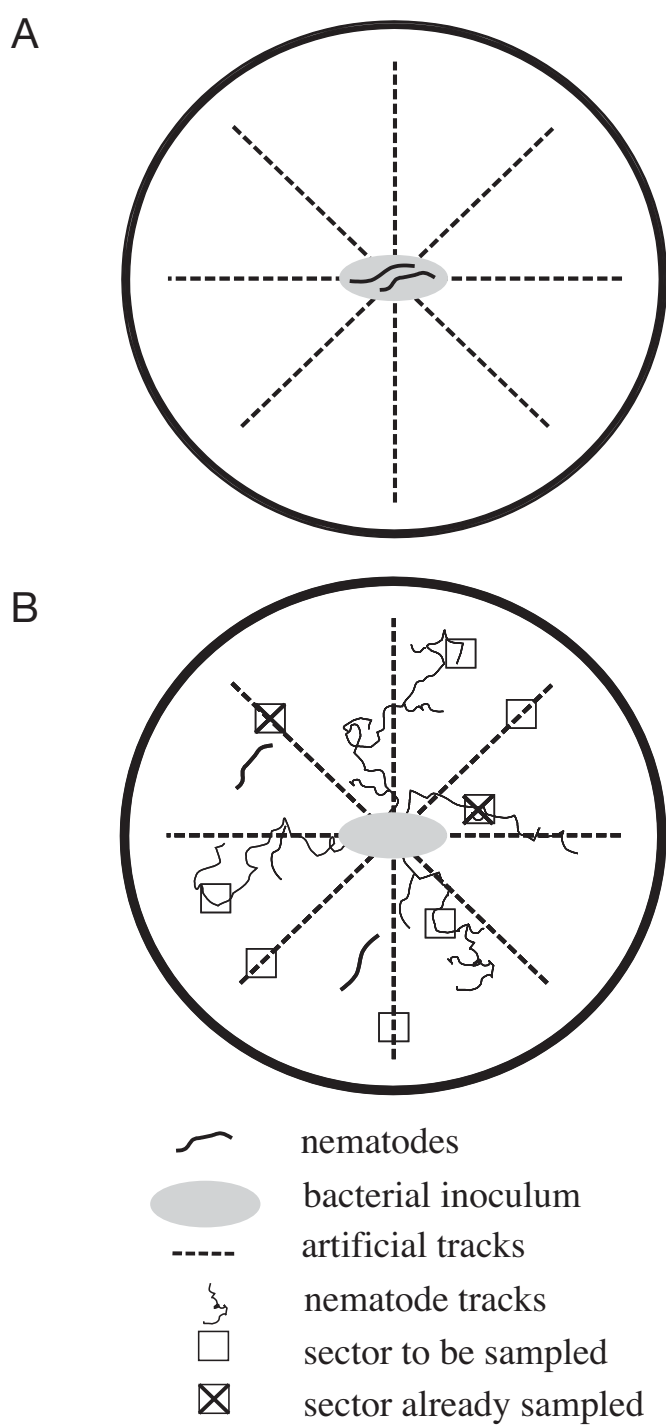

Fig. 1. Schematic representation of the experimental set-up, with illustration of (A) time zero and (B) 4 d situation. The microcosms are $5 \mathrm{~cm}$ diameter petri dishes coated with an agar layer

we chose a species of the omnivorous/facultatively predatory nematode genus Adoncholaimus, i.e. A. fuscus, for our experiments. In addition, we performed experiments with the bacterivorous Geomonhystera disjuncta, a species typically associated with decaying macrophyte detritus and producing conspicuous mucus tracks on agar media (T. Moens unpubl. data). G. disjuncta was obtained from synxenic laboratory cultures (Moens \& Vincx 1998), whereas A. fuscus was obtained from Paulina intertidal flat sediment by a simple decantation procedure. Each petri dish received 2 adult $A$. fuscus or 5 adult $G$. disjuncta (A. fuscus being considerably larger and more motile than G. disjuncta). 
Plates were incubated in the dark at $17^{\circ} \mathrm{C}$ for an $8 \mathrm{~d}$ period. Every second day, we used sterile forceps to take small samples of (1) the central inoculum, (2) the artificial tracks, and (3) the nematode tracks. These were subsequently inoculated in broth $(0.2 \mathrm{~g}$ of Bacto beef extract [DIFCO] and $0.33 \mathrm{~g}$ of Bacto peptone [DIFCO] in 11 of artificial seawater), and we characterised the dominant bacterial strains. All spots to be sampled over the entire $8 \mathrm{~d}$ period were marked upon the first sampling, such that (1) at later sampling occasions we were always sure to sample from a nematode track generated at the beginning of the incubation, and (2) a single spot could never be sampled twice.

For the characterisation of bacteria, aliquots of bacteria grown on broth were first diluted and spread on 'Marine Agar' plates (37.4 g Marine Broth [DIFCO] + $10 \mathrm{~g}$ Bacto agar [DIFCO] in $1 \mathrm{l}$ of water) and frequencies of different colony types were scored. All pure cultures obtained at the highest dilution, representing the different colony types observed, were characterised by fatty acid methyl ester (FAME) profiling (Bertone et al. 1996), following the procedures detailed in Huys et al. (1994). Prior to FAME profiling, bacterial isolates were grown on Trypticase Soy Agar (DIFCO) supplemented with $2 \% \mathrm{NaCl}$ for $24 \mathrm{~h}$ at $28^{\circ} \mathrm{C}$. The isolates were identified using our own FAME database that contains 52000 profiles covering most currently known bacterial genera. All our isolates had profiles very similar to those of known species in the reference database and are therefore referred to here as putative species; however, other molecular analyses, such as $16 \mathrm{~S}$ rDNA sequencing and DNA-DNA hybridisations, would be required to confirm their exact species identity.

All treatments were set up in triplicate, but samples from the 3 replicates of a single treatment were pooled together in broth. Colony plating was always performed in duplicate, but these duplicate plates consistently gave (nearly) identical results.

Similarity between bacterial communities from inocula, artificial tracks and nematode tracks was analysed with multidimensional scaling (MDS) and groupaverage linking on presence/absence data using the Dice similarity coefficient, which is identical to the Bray-Curtis coefficient when this is calculated for presence/ absence data (Clarke \& Warwick 1994).

\section{RESULTS AND DISCUSSION}

A total of 12 and 11 colony 'morphotypes' were found and isolated from the experiments with Adoncholaimus fuscus and Geomonhystera disjuncta, respectively. FAME analysis assigned these to 15 different putative bacterial species, 7 in the treatments with $A$. fuscus (Table 1) and 8 in those with G. disjuncta (not shown); 2 (in 1 treatment) to 7 bacterial species were found per bacterial inoculum.

Even though this experimental set-up generally yielded very low microbial diversity, we almost consistently found lower bacterial diversity on nematode tracks than in the central inoculum or on the artificial tracks (Table 1). In fact, all bacterial strains isolated from Adoncholaimus fuscus tracks could be assigned to a single species, Pseudoalteromonas tetraodonis. Moreover, while there were always 3 or 4 colony morphotypes of this bacteria in the inocula and artificial tracks of the A. fuscus treatments, only 1 to (mostly) 2 were recovered from $A$. fuscus tracks. MDS and groupaverage linking always separated nematode tracks from central inocula, artificial track communities typically being interspersed between central inoculum communities and, to a lesser extent, nematode track communities (Fig. 2).

Geomonhystera disjuncta tracks were always colonised by Photobacterium angustum/Vibrio anguillarum and by Pseudomonas pertucinogena. In just 1 of 4 G. disjuncta treatments, a third bacteria, Pseudoalteromonas nigrifaciens, was recovered from nematode tracks. Multivariate analysis generally yielded similar but less consistent and less pronounced results than in Adoncholaimus fuscus treatments (Fig. 2).

The above results suggest that nematode mucus secretions can influence bacterial community composition. Hitherto, nematode impacts on microbial communities have mostly been viewed from the angle of grazing effects. Recently, De Mesel et al. (2003, 2004) observed variable impacts of nematode grazers on microbial activity and community structure, depending on nematode species identity. They also found that structuring effects may even show up at low grazing pressure, implying selective grazing and/or other, indirect interactions. Nematode mucus may be at the basis of 1 such type of indirect interaction.

It is not a novel observation that free-living aquatic nematodes can produce mucus. Certain species from intertidal mudflats build tubes consisting of sediment and small organic particles glued together by mucus secretions from, e.g., the ventral gland, affecting sediment stability and, at the same time, probably offering shelter against both hydrodynamic impacts and predation (Nehring et al. 1990, Nehring 1993). Mucus production from ventral and caudal glands is widespread. Riemann \& Schrage (1978) hypothesised a gardening mechanism, where the nematodes stimulate growth of bacteria and then use them as food; this is not necessarily restricted to interactions with bacteria (Warwick 1981, Jensen 1996). Species of the genus Adoncholaimus do not rely substantially on bacteria as a food source (Moens et al. 1999), but this does not exclude the possibility that Adoncholaimus utilises certain 
Table 1. Identity and diversity of bacterial strains found on nematode (Adoncholaimus fuscus) tracks, artificial tracks and central inocula over an $8 \mathrm{~d}$ incubation period with samplings every second day. Numbers refer to the day(s) on which bacteria were found (A: absent over the whole incubation). Bacterial diversity (number of bacterial species found over the entire $8 \mathrm{~d}$ incubation) is indicated within parentheses

\begin{tabular}{|c|c|c|c|c|c|c|c|}
\hline & $\begin{array}{c}\text { Pseudo- } \\
\text { alteromonas } \\
\text { tetraodonis }\end{array}$ & $\begin{array}{c}\text { Pseudo- } \\
\text { alteromonas } \\
\text { haloplanktis }\end{array}$ & $\begin{array}{l}\text { Shewanella } \\
\text { putrefaciens }\end{array}$ & $\begin{array}{l}\text { Sphingopyxis } \\
\text { macrogoltabida }\end{array}$ & $\begin{array}{l}\text { Brevundimonas } \\
\text { vesicularis }\end{array}$ & $\begin{array}{c}\text { Gluconobacter } \\
\text { sp. }\end{array}$ & $\begin{array}{c}\text { Arthrobacter } \\
\text { viscosus }\end{array}$ \\
\hline \multicolumn{8}{|l|}{ Sandy sediment } \\
\hline Centre (3) & $2,4,6,8$ & $2,4,6,8$ & $\mathrm{~A}$ & $\mathrm{~A}$ & $\mathrm{~A}$ & $\mathrm{~A}$ & 2 \\
\hline Artificial track (2) & $2,4,6,8$ & $4,6,8$ & A & $\mathrm{A}$ & $\mathrm{A}$ & A & $\mathrm{A}$ \\
\hline Nematode track (1) & $2,4,6,8$ & A & A & $\mathrm{A}$ & $\mathrm{A}$ & $\mathrm{A}$ & $\mathrm{A}$ \\
\hline \multicolumn{8}{|c|}{ Ulva lactuca (decomposing) } \\
\hline Centre (5) & $2,4,6,8$ & 8 & $2,4,6,8$ & 8 & 6,8 & A & $\mathrm{A}$ \\
\hline Artificial track (5) & $2,4,6,8$ & 8 & $2,4,6,8$ & 8 & 8 & $\mathrm{~A}$ & $\mathrm{~A}$ \\
\hline Nematode track (1) & $2,4,6,8$ & $\mathrm{~A}$ & $\mathrm{~A}$ & A & $\mathrm{A}$ & A & $\mathrm{A}$ \\
\hline \multicolumn{8}{|c|}{ Spartina anglica (standing dead plant, roots excluded) } \\
\hline Centre (4) & $2,4,6,8$ & 8 & 2,8 & 6 & A & A & A \\
\hline Artificial track (4) & $2,4,6,8$ & 8 & 8 & 6,8 & A & A & A \\
\hline Nematode track (1) & $2,4,6,8$ & A & A & A & A & A & A \\
\hline \multicolumn{8}{|c|}{ Muddy sediment (in salt marsh) } \\
\hline Centre (3) & $2,4,6,8$ & $2,4,6,8$ & A & A & A & 2 & A \\
\hline Artificial track (3) & $2,4,6,8$ & $2,4,6$ & A & A & A & 2 & A \\
\hline Nematode track (1) & $2,4,6,8$ & A & A & A & A & A & A \\
\hline \multicolumn{8}{|c|}{ Bacteria in synxenic stock cultures of Geomonhystera disjuncta } \\
\hline Centre (4) & $2,4,6,8$ & A & 2,4 & A & $2,4,6$ & $2,4,6,8$ & A \\
\hline Artificial track (3) & $2,4,6,8$ & 2 & A & A & A & 8 & A \\
\hline Nematode track (1) & $2,4,6,8$ & $\mathrm{~A}$ & A & $\mathrm{A}$ & $\mathrm{A}$ & $\mathrm{A}$ & $\mathrm{A}$ \\
\hline \multicolumn{8}{|c|}{ Fucus vesiculosus (live thalli) } \\
\hline Centre (3) & $2,4,6,8$ & 6 & 4,6 & $\mathrm{~A}$ & A & A & A \\
\hline Artificial track (1) & $2,4,6,8$ & A & A & A & $\mathrm{A}$ & A & A \\
\hline Nematode track (1) & $2,4,6,8$ & $\mathrm{~A}$ & $\mathrm{~A}$ & $\mathrm{~A}$ & $\mathrm{~A}$ & $\mathrm{~A}$ & $\mathrm{~A}$ \\
\hline
\end{tabular}

bacteria-derived nutritive compounds. Alternatively, Adoncholaimus, and perhaps other nematodes, may produce exo-enzymes, which can start the initial decomposition of complex molecules. This would promote establishment and growth of bacterial populations that take over organic matter decomposition, with both nematodes and bacteria then feeding on the nutritious 'soup' of dissolved (DOM) and small particulate organic matter released from this shared use of enzymes (Riemann \& Helmke 2002).

Geomonhystera disjuncta is a bacterivore typical of detrital microhabitats in intertidal areas and is relatively easily culturable on agar media with bacteria as food (Vranken et al. 1988, Moens \& Vincx 1998). We have often observed this species to produce prominent mucus tracks on the surface of agar layers and to deposit its eggs along these tracks. As a bacterivore, this mechanism may ensure that eggs hatch in a foodrich micro-environment. Alternatively, as a typical inhabitant of phytodetrital deposits in (often wavewashed) intertidal environments, the mucus may simply help G. disjuncta in attaching eggs to the substrate, much like many nematodes use secretions from the caudal glands for adhesion.
The dominant bacteria associated with nematode tracks in our experiments were quite similar for both nematode species: Pseudoalteromonas tetraodonis was associated with Adoncholaimus fuscus tracks, and Pseudomonas pertucinogena, with Geomonhystera disjuncta tracks. In addition, the latter always contained Photobacterium angustum/Vibrio anguillarum and on 1 occasion Pseudoalteromonas nigrifaciens. Note that only 1 bacterial inoculum used with G. disjuncta contained $P$. tetraodonis. The bacterial strains isolated in this study are commonly found in a variety of aquatic environments (see e.g. Ivanova et al. 2003, Skovhus et al. 2004, Thompson et al. 2004).

As for the exact benefits of this nematode-microbial relationship for the nematodes, it is not clear whether or how nematode mucus stimulates bacterial growth. In addition to benefiting from any exo-enzymatic activity in the mucus (Riemann \& Helmke 2002), bacteria may simply use the mucus for attachment or feed on it. The composition - and potential nutritive value for bacteria - of the nematode mucus is poorly known, but it does apparently contain a substantial share of acid mucopolysaccharides (Nehring et al. 1990). In addition, $\mathrm{C} / \mathrm{N}$ ratios of nematodes tend to be 

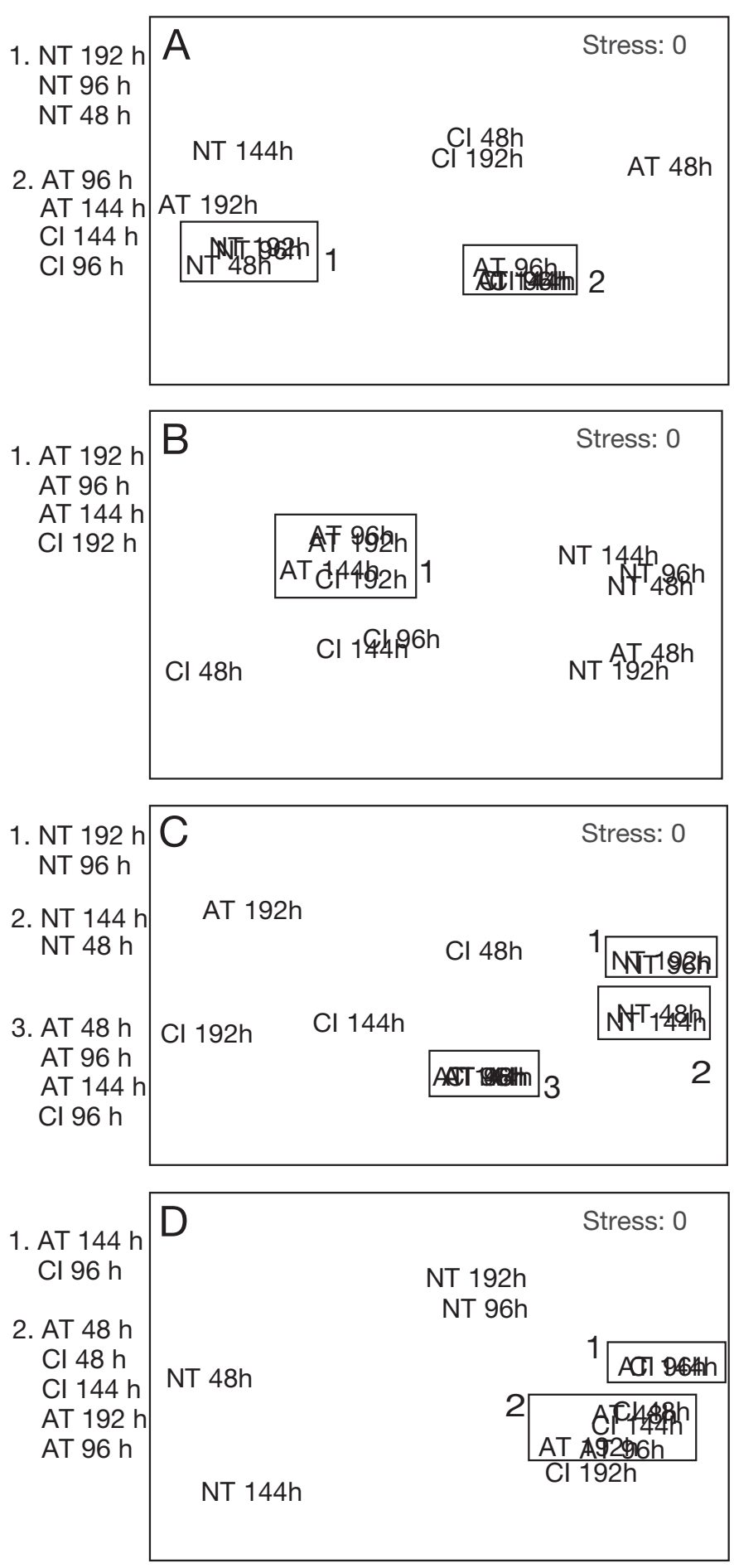

Fig. 2. MDS of bacterial community composition (based on presence/absence data) in inocula, artificial tracks and nematode tracks after 48, 96, 144 and $192 \mathrm{~h}$. (A-C) Examples of treatments with the nematode Adoncholaimus fuscus; bacterial inoculum derived from (A) is muddy salt marsh sediment, from (B) is fine to medium sandy sediment on a tidal flat and from (C) is decaying Ulva lactuca. (D) Example of treatment with Geomonhystera disjuncta; inoculum derived from muddy salt marsh sediment higher than those of bacteria (Anderson et al. 1983, Ferris et al. 1997), so nematodes feeding on bacteria obtain $\mathrm{N}$ in excess of their $\mathrm{N}$ requirements. Nematodes thus typically excrete $\mathrm{N}$-rich products and, depending on their nutritional status and on environmental conditions (especially the oxygen regime), void a variety of organic molecules, including amino acids, glycerol, L-lactate, acetate, etc. (Bolla 1980, Foll et al. 1999), which may serve as a source of food or nutrients $(\mathrm{N})$ for bacteria. In addition, a variety of dissolved organic and inorganic molecules have been shown to sorb to microbial exopolymer secretions (Decho 1990); similar sorption of nutritious compounds to nematode mucus may occur, depending on the chemical composition of the nematode mucus. It is indeed unlikely that the nematode mucus in itself would provide sufficient carbon and nutrients for the dense microbial growth observed on the nematode tracks. In turn, bacteria growing on mucus tracks may be a food source for nematodes or provide nematodes with access to nutritious compounds (see above). In another peculiar form of mutualism in aquatic environments, snails of the genus Littoraria facilitate growth of fungi on live cordgrass Spartina through their grazing activity and faecal pellet production, while benefiting themselves from feeding on fungal hyphae (Silliman \& Newell 2003).

Furthermore, free-living aquatic nematodes are generally more mobile than bacteria and may therefore act as vectors transporting bacteria to new resource patches. Nematodes display chemotaxis along cues informative of suitable microhabitats (Riemann \& Schrage 1988, Höckelmann et al. 2004). Oncholaimid nematodes are particularly mobile and aggregate efficiently on fresh deposits of organic matter (Lorenzen et al. 1987, Prein 1988). Neither Adoncholaimus fuscus nor Geomonhystera disjuncta is prominently coated with bacteria, and there are at present no indications that specific microbiota associate with these nematodes, as in some nematode-bacteria symbiotic relations (Polz et al. 2000, Ott et al. 2004).

No consistent temporal trends in bacterial community composition were found, but while composition and diversity of bacteria in inoculum and artificial tracks typically varied with time, they were constant over the $8 \mathrm{~d}$ incubation on nematode tracks. We had anticipated 1 or a few opportunistic bacteria to colonise nematode tracks instantly and other strains to develop during the course of the experiment, but the latter was never the case. On artificial tracks and in the inoculum spot we often found temporal shifts in community structure. This suggests that nematodes not only promote substrate colonisation by 1 or a few opportunistic strains, but may also facilitate these strains to maintain their dominance. A relevant observation in this respect 
is that-especially in Adoncholaimus fuscus experiments - there were 2 distinct types of nematode tracks: large main tracks and narrower side tracks. In addition to a time effect (bacteria start spreading from the nematode tracks thus widening them), the 2 types of tracks in our study originate from the fact that A. fuscus moves along a main track, but regularly makes side excursions, then moves backwards again onto the main track. As such, main tracks - or at least parts of them - are visited several times, while side tracks are visited only once. If the nematodes produce mucus continuously, main tracks will receive substantially more of it than side tracks, and as a result the mucus effect may be more pronounced in main tracks than in side tracks. In the present study, we only sampled from main tracks.

The results presented here have to be interpreted with caution since the experimental design - with extensive utilisation of nutrient-rich growth mediapromoted the growth of a low-diversity microbial community dominated by readily culturable bacteria. The need for visible and easy-to-'handle' nematode tracks made initial trials on artificial media inevitable, but additional 'culture' steps could, in future work, be avoided by using microbial fingerprinting methods. In a next step, artificial media should be replaced by natural substrates, such as sediment. However, while the identity of the bacteria colonising nematode tracks will likely be different under more natural conditions, the fact that differences in community diversity and composition between artificial tracks and nematode tracks were even found in such low-diversity communities strongly suggests that nematode mucus secretions do affect bacterial community structure. Elucidation of the underlying mechanisms will require, e.g., a compositional analysis of the nematode mucus. Bacteria, for instance, also grow on nematode mucus tracks in nutrient-poor agar media (Riemann \& Helmke 2002), but in our study they did so at a much slower rate and at lower densities.

Although the exact nature and implications of these intricate nematode-microbial interactions remain to be elucidated, their effects for the functioning of microbial food webs are potentially far-reaching. Nematodes may transport specific bacteria to resource patches and decidedly affect their colonisation and succession patterns, which may well have implications for important ecosystem functions, such as decomposition and mineralisation. Such 'founder effects' may be quite widespread, and should be taken into account in future research on meiofauna-microbiota relations.

Acknowledgements. This work was financially supported by Ghent University through BOF-Projects 011060002 and 1205398 and by the Flemish Fund for Scientific Research
(FWO) (Project 31521704). Christine Van der heyden skilfully assisted in manuscript preparation. T.M. is a postdoctoral research fellow of the FWO.

\section{LITERATURE CITED}

Alkemade R, Wielemaker A, Hemminga MA (1992a) Stimulation of Spartina anglica leaves by the bacterivorous marine nematode Diplolaimelloides bruciei. J Exp Mar Biol Ecol 159:267-278

Alkemade R, Wielemaker A, de Jong SA, Sandee AJJ (1992b) Experimental evidence for the role of bioturbation by the marine nematode Diplolaimella dievengatensis in stimulating the mineralization of Spartina anglica detritus. Mar Ecol Prog Ser 90:149-155

Aller RC, Aller JY (1992) Meiofauna and solute transport in marine muds. Limnol Oceanogr 37:1018-1033

Anderson RV, Gould WD, Woods LE, Cambardella C, Ingham RE, Coleman DC (1983) Organic and inorganic nitrogenous losses by microbivorous nematodes in soil. Oikos 40: $75-80$

Bertone S, Giacomini M, Ruggiero C, Piccarolo C, Calegari L (1996) Automated systems for identification of heterotrophic marine bacteria on the basis of their fatty acid composition. Appl Environ Microbiol 62:2122-2132

Bolla R (1980) Nematode energy metabolism. In: Zuckerman BM (ed) Nematodes as biological models, Vol 2. Academic Press, New York, p 165-192

Clarke KR, Warwick RM (1994) Change in marine communities: an approach to statistical analysis and interpretation. Plymouth Marine Laboratory, Plymouth

Decho AW (1990) Microbial exopolymer secretions in ocean environments: their role(s) in food webs and marine processes. Oceanogr Mar Biol Annu Rev 28:73-153

De Mesel I, Derycke S, Swings J, Vincx M, Moens T (2003) Influence of bacterivorous nematodes on the decomposition of cordgrass. J Exp Mar Biol Ecol 296:227-242

De Mesel I, Derycke S, Moens T, Van der Gucht K, Vincx M, Swings J (2004) Top-down impact of bacterivorous nematodes on the bacterial community structure: a microcosm study. Environ Microbiol 6:733-744

Ferris H, Venette RC, Lau SS (1997) Population energetics of bacterial-feeding nematodes: carbon and nitrogen budgets. Soil Biol Biochem 29:1183-1194

Findlay S, Tenore KR (1982) Effect of a free-living marine nematode (Diplolaimella chitwoodi) on detrital carbon mineralization. Mar Ecol Prog Ser 8:161-166

Foll RL, Pleyers A, Lewandovski GJ, Wermter C, Hegemann V, Paul RJ (1999) Anaerobiosis in the nematode Caenorhabditis elegans. Comp Biochem Physiol B Biochem Mol Biol 124:269-280

Heip C, Vincx M, Vranken G (1985) The ecology of marine nematodes. Oceanogr Mar Biol Annu Rev 23:399-489

Höckelmann C, Moens T, Jüttner F (2004) Odor compounds from cyanobacterial biofilms acting as attractants and repellents for free-living nematodes. Limnol Oceanogr 49: 1809-1819

Huys G, Vancanneyt M, Coopman R, Janssen P, Falsen E, Altwegg M, Kersters K (1994) Cellular fatty acid composition as a chemotaxonomic marker for the differentiation of phenospecies and hybridization groups in the genus Aeromonas. Int J Syst Bacteriol 44:651-658

Ingham RE, Trofymow JA, Ingham ER, Coleman DC (1985) Interactions of bacteria, fungi and their nematode grazers: effects on nutrient cycling and plant growth. Ecol Monogr 55:119-140 
Ivanova EP, Sawabe T, Hayashi K, Gorshkova NM and 5 others (2003) Shewanella fidelis sp. nov., isolated from sediments and sea water. Int J Syst Evol Microbiol 53:577-582

Jensen P (1996) Burrows of marine nematodes as centres for microbial growth. Nematologica 42:320-329

Johannes RE (1965) Influence of marine protozoa on nutrient regeneration. Limnol Oceanogr 10:434-442

Lillebø AI, Flindt MR, Pardal MA, Marques JC (1999) The effect of macrofauna, meiofauna and microfauna on the degradation of Spartina maritima detritus from a salt marsh area. Acta Oecol 20:249-258

Lorenzen S, Prein M, Valentin C (1987) Mass aggregations of the free-living marine nematode Pontonema vulgare (Oncholaimidae) in organically polluted fjords. Mar Ecol Prog Ser 37:27-34

Moens T, Vincx M (1998) On the cultivation of free-living estuarine and marine nematodes. Helgol Meeresunters 52:115-139

Moens T, Verbeeck L, Vincx M (1999) Feeding behaviour of a predatory and a facultatively predatory marine nematode (Enoploides longispiculosus and Adoncholaimus fuscus). Mar Biol 134:585-593

Nehring S (1993) Tube-dwelling meiofauna in marine sediments. Int Rev Ges Hydriobiol 78:521-534

Nehring S, Jensen P, Lorenzen S (1990) Tube-dwelling nematodes: tube construction and possible ecological effects on sediment-water interfaces. Mar Ecol Prog Ser 64:123-128

Ott J, Bright M, Bulgheresi S (2004) Symbioses between marine nematodes and sulfur-oxidizing chemoautotrophic bacteria. Symbiosis 36:103-126

Editorial responsibility: John Dolan, Villefranche-sur-Mer, France
Polz MF, Ott JA, Bright M, Cavanaugh CM (2000) When bacteria hitch a ride. Am Soc Microbiol Newsl 66:531-539

Prein M (1988) Evidence for a scavenging lifestyle in the freeliving nematode Pontonema vulgare (Enoplida, Oncholaimidae). Kiel Meeresforsch 6:389-394

Riemann F, Helmke E (2002) Symbiotic relations of sedimentagglutinating nematodes and bacteria in detrital habitats: the enzyme-sharing concept. PSZN I: Mar Ecol 23:93-113

Riemann F, Schrage M (1978) The mucus-trap hypothesis on feeding of aquatic nematodes and implications for biodegradation and sediment texture. Oecologia 34:75-88

Riemann F, Schrage M (1988) Carbon dioxide as an attractant for the free-living marine nematode Adoncholaimus thalassophygas. Mar Biol 98:81-85

Silliman BR, Newell SY (2003) Fungal farming in a snail. Proc Natl Acad Sci USA 100:15643-15648

Skovhus TL, Ramsing NB, Holmstrom C, Kjelleberg S, Dahllof I (2004) Real-time quantitative PCR for assessment of abundance of Pseudoalteromonas species in marine samples. Appl Environ Microbiol 70:2373-2382

Thompson FL, Iida T, Swings J (2004) Biodiversity of Vibrios. Microbiol Mol Biol Rev 68:403-431

Vranken G, Herman PMJ, Heip C (1988) Studies of the lifehistory and energetics of marine and brackish-water nematodes. I. Demography of Monhystera disjuncta at different temperature and feeding conditions. Oecologia 77:296-301

Warwick RM (1981) Survival strategies of meiofauna. In: Jones NV, Wolff WJ (eds) Feeding and survival strategies of estuarine organisms. Plenum Press, New York, p 39-52

Submitted: December 27, 2004; Accepted: May 27, 2005

Proofs received from author(s): June 28, 2005 